\title{
The Normative Framework of Labour Law
}

\author{
Nuna Zekić*
}

\section{Introduction}

The challenges that confront contemporary labour regulation often go to the core of labour law as an academic field: whether and how to protect the worker as the weaker party to the employment contract. Therefore, it is not uncommon for labour law scholars to 'reflect on the nature of labour law and where it is, or should be, going' (Howe et al., 2017a, p. 5). In doing so, most scholars are quite active in challenging traditional conceptions of the field and articulating alternative paradigms (p. 1). For example, the rise of non-standard forms of working arrangements, such as those in the so-called gig economy, is currently being discussed, including the question of whether the law should be reformed in order to better accommodate these types of working relationships (e.g. Todolí-Signes, 2017, pp. 241-268). External actors, such as the European Commission and the World Bank, have also been known to place pressure both on the Western and on the transitional and developing countries to adopt labour law reforms (e.g. Bruun et al., 2014; Hinarejos, 2016, pp. 231-250; World Bank, 2018).

Labour law is far from being a tranquil area; therefore, evaluative or normative research questions are often raised. It is common for academic labour lawyers to describe the legal rules and to suggest strategies through which the existing rules could be reformulated in order to address a certain problem (Hammond \& Ronfeldt, 1998, p. 229). Often, there is a mix of a positivist approach and a normative approach. This is not different from the legal scholarship in general. Normative research is seen by many as essential to, and typical of, legal scholarship (e.g. Bell, 2011, pp. 155-176; Kestemont, 2015, p. 375). In fact, some scholars think that the question 'what the law should be' is at the heart of legal scholarship and that it distinguishes legal scholarship from other disciplines (Smits, 2009a, p. 70; 2009b, p. 49). Even though one can disagree with the latter, since other disciplines deal with normative questions as well, many will underline that normative questions are important for legal scholarship. However, as Taekema explains, such normative questions need a different kind of framework (than in case of descriptive and explanatory questions): 'not one that can explain why law is what it is, but a framework that can provide arguments for a judgment that the law is good or bad' (Taekema, 2018, p. 6). The normative framework can provide a yardstick, a set of standards or values that can serve to support a judgment (p. 7). 
One of the ways to construct such a framework is to use the underlying values and principles that are common to law, such as 'freedom of contract'. However, some scholars have argued that the 'younger', more instrumental fields of law, such as labour law or tax law, lack a sufficiently developed normative framework (Smits, 2009 , p. 88). Focusing on the formulated policy goals and assessing whether these goals have been reached by the legal measures is then considered to be a more useful method. Furthermore, even when one assumes that instrumental fields of law do in fact have a normative framework, the normative framework of labour law is often reduced to 'protection of the worker', since this is considered to be the basic principle of labour law.

Labour law is indeed very much connected to government policy. But does that mean that labour law, as a field of law, does not have an internal normative framework? A quick survey of the vast amount of labour law literature would show that labour law scholars would disagree with this proposition. However, if we assumed that it indeed does have a normative framework, to what extent is this framework clearly defined? Can we use it to make normative claims about the future development of labour law? To answer these questions, the article looks at (labour law) literature on the normative and methodological aspects of labour law scholarship. Overall, the normative framework and the related methodological aspects have often been left rather implicit. ${ }^{1}$ This proves to be exemplary for legal research in general (Taekema, 2018, p. 7). However, there have been a few important contributions in recent years that directly address such questions. It is important to examine and compare these works, since the normative questions concerning labour law tend to have great social relevance. Furthermore, it can be argued that the autonomy of labour law as a legal field is dependent on its normative framework (cf. Freedland, 2015, pp. 29-44). Indeed, it has been maintained that labour law is 'in a conceptual and normative crisis' (Fudge, 2011, p. 124). Even when we are 'merely' describing the law and there is room for interpretation - and there often is - the act of interpretation also requires us to pay attention to the law's normative purpose. ${ }^{2}$

The literature that has been studied for this purpose is mostly international English-language literature, but, since labour law is still very much a national matter, this international literature is complemented by Dutch scholarly works in this field. The article first sketches the context of labour law research and then moves on to explore two ways to approach normative research: internal and external to law. Next - in paragraph 4 - the article goes deeper into the internal normative framework of labour law by reviewing and clarifying this framework as it is presented in labour law literature. In paragraph 5 , the internal normative framework is evaluated by asking whether the framework is clearly defined in order to be

1 Consider the recent special issue on 'Labour Law Research Methodologies' of the International Journal of Comparative Labour Law and Industrial Relations where - even according to the editors - too little attention is being paid to normative research, see Davidov and Alon-Shenker (2017, p. 3).

2 When interpreting the law, the normative element is quite often camouflaged (Smits, 2009, p. 73). For a different opinion, see, e.g., O’Donnell (2017, p. 67). 
used to answer normative questions about the future of labour law. Paragraph 6 presents concluding remarks.

\section{Labour Law and the World of Work}

Labour lawyers use the same legal method as other lawyers: they research, analyse and synthesize legal doctrine. Labour law scholarship is, however, largely orientated towards what is described as 'the real world' of employment relations: the day-to-day exchange and interactions between workers and employers on an individual and collective level (cf. Hammond \& Ronfeldt, 1998, p. 229). This 'world of work' is always the context in which labour lawyers perform their legal analysis. ${ }^{3}$ Traditionally, as a discipline, labour law has had a close relationship with the multidisciplinary field of industrial relations, even though this seems to be less the case in continental Europe than in English-speaking countries (Bogg, 2017, p. 7; Collins, 1997, p. 297). A considerable part of labour law research is, however, evaluative or normative. The intention of evaluative research is usually to consider the relationship between labour law and the world of work. Many academics in this field wish to address the impact of legal norms and judicial decisions on the interactions and exchanges between employers and workers at the workplace and in collective bargaining. In this context, it has been stressed that we need more empirical research in order to address such evaluative questions (Hammond \& Ronfeldt, 1998, pp. 227-238). As in the case of some other fields of legal scholarship, advocates of empirical legal research have demonstrated that the traditional doctrinal method has serious constraints. It is argued that by relying on traditional legal research methods, our evaluations of the impact of the law tend to be based on untested behavioural assumptions and are more or less fact-free (Hammond \& Ronfeldt, 1998, p. 233). To be able to really say something about the effects of legal regulations on the behaviour in the real world, we need evidence based on systematic empirical sources (e.g. Blackham \& Ludlow, 2017, p. 1). This implies (labour) lawyers incorporating methods used by social scientists and moving towards interdisciplinary research.

Social science research and empirical evidence can indeed be very useful for labour law scholarship. As Slinn has shown, it can help to measure the effectiveness of a law, to determine whether the law has achieved its intended purpose, or whether it has had unintended and possibly undesirable consequences (Slinn, 2005, p. 297). We must not, however, forget that empirical facts do not make up the law. Empirical facts cannot tell us whether the examined situation was 'just' or 'fair'; social science research cannot tell us whether something is 'good' or 'bad' (Slinn, 2005, p. 309). Besides empirical facts, we need a normative framework. If we summarize the goal of legal scholarship in labour law as simply wanting to

3 Other fields of law might also be strongly interwoven with other disciplines, e.g. penal law and criminology, competition law and economics. 
improve labour regulation - an objective many legal scholars share (Kestemont, 2015, p. 375) - then we need to know towards what we are improving.

To this end, many scholars embrace an external perspective. In labour law, theories from the (political) economy, such as theories on efficiency, are often used to assess labour law norms. In fact, efficiency is stated by some scholars as one of the principles labour law aims to advance, as we will see in paragraph 4 . Besides evaluating the impact of labour law on the day-to-day exchange and interaction between workers and employers on an individual and collective level, many scholars have moved towards discussing and evaluating the relationship between labour law and (the functioning of) the labour market in general. This labour market approach has gained importance in legal research and is considered by many to be a useful - if not the most useful - perspective for the study of labour law. ${ }^{4}$ It can be argued that this broadening of the view of the relationship between employers and workers and their representatives towards the functioning of the labour market as a whole has made the task of labour law research more difficult. When we take into account the fact that empirical legal research was never an easy task for lawyers untrained in qualitative and quantitative methods (cf. Genn et al., 2006, p. 9), this macro-level analysis raises even greater challenges for labour law scholars. After all, in order to really engage in the present economic debate, for example in the context of the EU internal market, the policies of the World Bank or the Organisation for Economic Cooperation and Development (OECD), where labour law is often considered as an undesirable distortion of the market, one needs to 'employ techniques that enable systematic and rigorous analysis of casual influences on economic performance' (Adams \& Deakin, 2017, p. 33). Legal scholars are usually not trained for such research. Besides this rather practical argument against the labour market approach as the only way to decide on normative questions, there is another, more fundamental, argument. On a closer look, the labour market approach is a normative framework in itself, and the traditional economic analysis is constrained by its ideology as well. As has been shown, it rests on the assumption that individual behaviour is the product of utility-maximizing decisions made by freethinking rational actors. Therefore, even though an economic analysis can be beneficial to labour lawyers, the question of what the law should be cannot be reduced to labour market analysis alone (Hammond \& Ronfeldt, 1998, p. 237). As indicated earlier, with normative questions we need to be clear about the normative framework.

\section{Internal and External Normative Frameworks}

In order to develop a normative framework systematically, it can be useful - as Taekema suggests - to distinguish between internal and external normative frameworks, even though this distinction is not always clear-cut (Taekema, 2018, 
p. 7; also see Kestemont, 2015, p. 373). In the case of the internal framework, the legal system itself provides the concepts required in order to study a certain legal or social development (cf. Westerman, 2011, p. 90). Internal frameworks are made up of principles, values or standards that are part of the law, like the freedom of contract or the security of property. The principles can be explicitly stated in positive law; in that case, they usually have the status of human or constitutional rights. However, they can also be 'implicitly presupposed' in positive law, still being part of the legal system (Taekema, 2018, p. 8). They are often seen as the foundations on which a certain legal field is built. The internal framework will often refer to the structure and the internal logic of the existing system. Using such principles as standards for evaluations, often means that doctrinal analysis is used normatively, by "critically considering the limits of current legal doctrine and suggesting how law could be changed to better reflect "important" values and social concerns' (Hammond \& Ronfeldt, 1998, p. 229).

External normative frameworks refer to theories about these principles or values, which are often grounded in social or political philosophy, since we are usually dealing with moral or political values (Taekema, 2018, p. 8). ${ }^{5}$ Such theories are usually less constrained by what is actually in force in particular legal systems (Bell, 2011, p. 157). Theories from disciplines other than philosophy can be used as well, such as sociology, history, economics, political science and public governance (Kestemont, 2016a, p. 158). However, the so-called 'philosophical foundations' of labour law were not examined thoroughly in the literature for a long time (Spector, 2006, p. 1119; see also Collins et al., 2018). This might seem surprising, but, as Bogg explains, it has to do with the strong attachment to sociological methods of enquiry (Bogg, 2017, p. 7) and the above explained connection to 'the world of work'. Furthermore, most scholars in this field are orientated more towards the practice than towards theory and philosophy. It can be said that labour law as a legal field has been more about the day-to-day politics than it has been about philosophy (p. 8).

However, by now, many different external normative frameworks have been used in modern labour law literature, although only a few examples are offered here. Apart from the labour market approach, mentioned earlier, the capability approach, as developed by Nussbaum and Sen, has received quite a lot of attention (e.g. Deakin \& Wilkinson, 2005; Langille, 2009, pp. 73-76). Teubner's theory of reflexive law has often been used in labour law scholarship; for example, as a lens through which to assess the developments in European labour law (Ashiagbor, 2005, pp. 217-241). Recently, the civic republican political theory has also been used 'to give a sketch of an alternative basis for intervention in the employment relationship' (e.g. Cabrelli \& Zahn, 2017a, pp. 339-364; also see Eleveld, 2019, pp. 207222). Taekema (2018, p. 8) suggests using policy aims as external frameworks, something that quite often happens in labour law writings. In this case, however, empirical research methods come in sight quite quickly. As explained above, one

5 For examples, she refers to the liberal political theory of Rawls and the critical theory of Unger: Rawls (1971) and Unger (1986). 
needs to rely on empirical facts when assessing whether a certain policy goal is met. Furthermore, these effects can change when the overall economic prospects change.

It is certainly not always possible to distinguish between internal and external reference frameworks. There can also be some confusion over whether something should be considered an internal or external framework. For example, Smits advocates comparative legal research as that is in his view the most important research method for evaluating different normative arguments, but he calls this an external normative perspective, since the arguments are drawn on the basis of the study of another legal system (Smits, 2009, pp. 45-58). Here we are concerned with the internal normative framework of labour law, which is in the first place drawn from the legal doctrine and in principle not from theories outside the law.

\section{4. 'The Idea of Labour Law'}

Going deeper into what labour law is actually about, we can now explore the internal perspective on labour law starting from its central legal concepts and moving towards the goals that labour law as a functional field aims to achieve. The employment contract is the central feature of labour law. In many legal systems, this makes labour law part of contract law, even though it is a special kind of contract. In the Netherlands, for example, the main legal rules concerning the employment contract can be found in the Civil Code. ${ }^{7}$ The employment contract has a dual character: there are both personal and proprietary aspects present. The proprietary aspects are manifested in the exchange of labour power for remuneration. The personal aspects are visible in the personal subordination of the employee. We can see these aspects in the definition of the employment contract, which usually reads as follows: An employment contract is a contract whereby one party, the employee, commits himself towards the opposite party, the employer, to perform labour in service of this opposite party in exchange for remuneration. ${ }^{8}$ Since the labour power cannot be separated from the employee as a human being, the employee is always personally involved in the execution of the contract. When performing labour under the employment contract, the employee is subordinated to the control or direction of the employer, according to the definition of the employment contract. Subordination of one party to the other is one of the central elements of the definition. This is why we can say that the unequal position between the employer and the employee is inherent to the employment contract. In addition, when we take into account the fact that most human beings need to work for their livelihood - most workers have no other means of income 
than wages ${ }^{9}$ - the unequal position vis-à-vis the employer (as regards the terms of the employment) becomes even more apparent. This is why it is generally accepted that in an employment relationship the worker is considered to be the weaker party, not only because he is economically dependent on the employer for income, but because he is also legally subordinated to this employer. ${ }^{10}$

In general, there are two main mechanisms in labour law that aim to compensate this inequality. First, there are substantive legislative rules that regulate the terms and conditions of the employment contract and generally limit the freedom of the employer. The employer needs to take these legal norms into account. These norms can set a certain minimum of rights, for example regarding wages, holidays, working hours, etc., or they can describe a certain procedure that the employer must follow, such as in the case of dismissal. The other mechanism is to legally provide for and stimulate collective organization and collective bargaining. It is believed that when workers bargain collectively, they are in a more equal bargaining position with the employer. It is usually the trade unions that bargain with the employer (or employer's organization) on behalf of the workers about the working conditions. These collective agreements are sometimes made generally binding by an administrative decree for the whole sector of the economy in order to have a level-playing field and to prevent competition regarding the working conditions. Collective bargaining can also be seen as a form of self-regulation, and in many countries in Europe it is the preferred form of worker protection. ${ }^{11}$ In addition, in some countries, like the Netherlands and Germany, this collective dimension is supplemented by a system of consultation and co-determination by works councils within firms.

In the legal doctrine, the prevalent view is that the regulation of the employment contract is designed in such a way as to protect the weaker party to the contract. However, there are also important aspects of labour law that in many jurisdictions have a public law character, such as health and safety regulations or working time regulations. This can influence the view on the internal normative framework. For example, the human rights approach may be very useful as well. Overall, however, 'protection of the employee' is for most legal scholars a clear basic principle of labour law. This principle is seen as part of the legal system even though it is (usually) not expressed as such in the law. The fact that it not only constitutes a basic principle of labour law, but also plays an important role in other fields of law, such as consumer law, only contributes to its significance.

Most labour law scholars will justify labour laws more or less in the preceding terms. There is a strand of scholars, however, that goes further, and articulates a

9 Most welfare states have some form of social benefits, but these social security systems are usually designed in such a way that there is a legal obligation to search for and accept (suitable) employment.

10 Much has been written on the inequality between workers and employers; in labour law literature, works of Hugo Sinzheimer and Otto Kahn-Freund are the most famous.

11 This explains why traditionally labour law as a discipline has been connected to industrial relations, where most scholars study trade unionism, collective bargaining and labour-management relations. 
set of principles or values that labour law aims to achieve, often grouped under the heading of 'social justice' (e.g. Davidov, 2016; Hendrickx, 2010a, p. 37). Protection of the worker is then often set in the framework of protection of human dignity (e.g. Arthurs, 2011, p. 18; Freedland \& Kountouris, 2011, pp. 371-376; Hendrickx, 2010a, p. 36; Rood, 1997, p. 149; Weiss, 2011, p. 44). In the quest to give meaning to the statement 'labour is not a commodity', upholding human dignity serves as the ultimate objective of labour law. Since labour law deals with power relations, enhancing human freedom has been articulated as the ultimate 'philosophy' for constructing normative arguments (Dukes, 2014, p. 198). ${ }^{12}$ Freedom is then essentially to be understood as emancipation of workers from their subordination to capital (p. 198). But others tend to describe human freedom in a slightly different way and argue for advancement of human capabilities as one of the labour law's goals (see Davidov, 2016, pp. 65-67 and the references there). Even though the collective part of the law can also be connected to human freedom, as it enables the workers to participate in the exercise of power, it has often been connected to democracy (p. 56). Giving workers voice in the governance of the workplace and ensuring that decisions are based on a compromise between competing interests is seen as crucial for ensuring the fairness of such decisions (p. 57).

In fact, labour law literature reveals a plurality of 'goals', 'objectives', 'principles' and 'values' underpinning labour law. Another 'major goal' of labour law is according to Davidov redistribution (of resources, power, and risks) or the advancement of distributive justice (Davidov, 2016, pp. 57-59). For example, minimum wage laws and collective bargaining laws can be seen as designed to redistribute. More recent and perhaps more policy-orientated are the goals of social inclusion, but also of income security (pp. 62-65) or stability (Freedland \& Kountouris, pp. 379-382). Various labour laws play an important part here: anti-discrimination laws, laws limiting dismissals and the use of flexible contracts, laws regarding working hours and work-life balance, etc. Sometimes, solidarity is mentioned as an underlying principle as well (Däuble, 2014, pp. 58-59; van der Heijden \& Noordam, 2001, pp. 87-90). These norms or values are not exclusive for labour law.

It is interesting to note that there can be another side to these values as well. Influential Dutch scholars have included responsibility and participation among the 'basic values' of labour and social security law, which seem to correspond with social inclusion. However, by including participation as a basic value of labour law they lay stress on the fact that in our society individuals have the responsibility to take part in society, preferably by performing waged labour (Van der Heijden \& Noordam, 2001, pp. 76-77, 93)..$^{13}$ This would explain the many duties - besides rights - in labour and social security law. ${ }^{14}$ An additional level of complexity may

12 Dukes follows here the opinion of Sinzheimer and Kahn-Freund. Davidov has also articulated 'emancipation/social equality' as one of the purposes of labour law, see Davidov (2016, p. 68).

13 Van der Heijden and Noordam aimed at identifying the basic values of labour law based on legislation reforms in the Netherlands approximately between 1980 and 2000.

14 In labour law, the duties are usually found in collective agreements (e.g. the duty to perform overtime), but they can be found in legislation as well; e.g. the duty to cooperate in activation policy and to accept other, better suitable jobs in case of sickness or disability. 
arise when the level of protection in the employment contract (especially protection against unlawful dismissal) is being reduced with the explicit aim to boost employment and to achieve better social inclusion. ${ }^{15}$

A rather interesting and, in this regard, more problematic goal found in the literature is that of efficiency. Choosing efficiency as the leading goal or one of the leading goals of labour law requires placing the functioning of the labour market as a central thread. In economic terms, labour markets are imperfect markets. They are rarely competitive, transaction costs are widespread and employers often have monopsony powers (e.g. Davidov, 2016, p. 65). Within this discourse, labour law is not seen as regulation that imposes costs and disturbs the market function - as is the orthodox economic view - but as a tool to address market failures and to enhance (competitiveness and) efficiency. Arguably, efficiency is not a goal in itself; rather, improving the operation of the labour market is.

It may seem only proper to take up efficiency among the goals (or principles) of labour law, since labour law does not only affect individual and collective work relations, but also the labour market and the macro economy as a whole. Labour market regulation should benefit all members of society ( $c f$. Cabrelli \& Zahn, 2017 b, p. 7). We can see this idea reflected in (almost) all important legislative reforms introduced in the past decades. They are often characterized by the intent to strike a balance on the labour market: a balance between flexibility and security. ${ }^{16}$ According to Hendrickx (2010a, p. 56), there is nothing wrong with asking how efficient our labour laws are in terms of productivity, competitiveness and employment creation. ${ }^{17}$ It is problematic, however, because when we take efficiency as the goal, the ultimate question is 'whether it will lead to greater efficiency, productivity and a better functioning labour market' (Cabrelli \& Zahn, 2017b, p. 8; see also Dukes, 2014, pp. 206-207). It is not obvious how this goal fits next to the goals of enhancing human dignity, redistribution, emancipation, social inclusion and income stability. It has been argued that it is not possible to pursue these goals simultaneously, since the efficiency discourse has 'an inherent danger in prioritising the economic over the social as the predominant unifying narrative' Cabrelli \& Zahn, 2017, p. 8. See also Dukes, 2014, pp. 206-207.

As problematic as this relationship might be, it is part of labour law. It is important to stress that the protective goals of labour law in Western countries have been developed in the framework of a market economy. As Fudge has put it: 'Labour law, even during its golden period, was concerned with production and protection.' (Fudge, 2011, p. 123) At the same time that labour law limits the employer's legal right to command, it also constitutes the legal authority of the employer and the subordination of the worker (Deakin, 2002, p. 187). It is true

15 See, for example, the European Employment Strategy (EES), the Employment Guidelines and the European social policy where 'flexicurity' is one of the guiding principles (Zekić, 2016, pp. 548-575).

16 E.g. in the Netherlands, major law reforms were introduced by the Act on Work and Security and the Act on Labour Market in Balance.

17 Obviously, this discourse largely corresponds with the 'law of the labour market' approach mentioned earlier. 
that there are protective laws, but the law also allows for human labour to be exchanged for goods in the first place, with risks of precariousness, poverty and exploitation in its wake. As Bogg explains, it is precisely this ambivalence that gives (labour and social security) law its moral urgency as (protective) regulatory activity (Bogg, 2017, p. 14). Furthermore, that regulatory activity is increasingly orientated towards competitiveness and efficiency instead of redistribution and human dignity. This is particularly true for (national) legislation enacted since the 1980s (e.g. Bruun \& Hepple, 2009, p. 31).

It is, therefore, possible to turn things around and to explain labour law as that part of law that regulates the employers' disposition over the workers' labour. In order to regulate it in a peaceful and effective way, labour law takes into account the interests of both sides. This happens, as Van Peijpe explains, more or less in accordance with the present balance of powers in the broad context of economic, social and political relations (van Peijpe, 1998, p. 34). This other narrative explains labour law as 'a body of law which continues to support and facilitate the infliction of many forms of precarity, exploitation and legal exclusion upon large and growing sectors of the labour force' (Freedland, 2015, p. 44).

\section{A Clearly Defined Internal Normative Framework?}

Where does the foregoing (rather general) exploration of labour law literature take us? We can see that it is possible to approach the internal normative framework of labour law in two ways: in a narrow and a broad way. The narrow approach focusses on the inequality between the parties to the employment contract and the creation of a counterbalance. The broader approach includes several different principles into the framework, which can be summarized under the heading of 'social justice'. Social justice includes references to power imbalances in society but is broader than that. It can include other principles mentioned before, such as democracy and social inclusion.

There is a wide variety of literature on the normative framework in the narrow sense, which spans a period of several decades. There is a considerable degree of conformity - at least in labour law literature - on the traditional 'inequality of bargaining power' rationale and the need to countervail this inequality. That does not mean, however, that there is no controversy on this point. On the contrary, the need to countervail the power imbalance has always been contested, as well as its ability to justify labour laws. ${ }^{18}$ Perhaps that is why the majority of labour law scholars have repeatedly felt the need to invoke, explain and perhaps even prove the existence of the power imbalance. In addition, to say that there is a considerable degree of conformity in the labour law literature on this point does not mean that labour laws are always interpreted in this way by the legislature, the courts or the scholars. There is, furthermore, a lively debate on the question of who 
should be protected by labour law, i.e. on the scope of labour law protection and on the extent and manner of protection. This debate is largely infused by the new forms of economic organizations (such as multinational groups of companies or digital platforms) who increasingly use various arrangements for the provision of work embedding either self-employed workers or small entrepreneurs (Razzolini, 2010, p. 278), sometimes with the explicit aim of avoiding the labour law protection granted to employees. At the same time, the strength and the coverage of collective bargaining - one of the main forms of labour protection - is declining as a consequence of decreasing trade union density (e.g. Hendrickx, 2010b, pp. 59-79), but also as a consequence of the subjection of the right to collective action to the economic freedoms of the internal market of the EU (e.g. Ashiagbor, 2009, pp. 222-266; Malmberg \& Sigeman, 2008, p. 1115-1146) and, recently, the structural reforms of collective bargaining models in countries that have received financial aid from the EU (Bruun et al., 2014). Despite the immense challenges facing traditional labour law protection, the need to countervail inequalities by legal mechanisms such as those constructed in labour law is constantly invoked and used by the majority of labour law scholars to justify and to evaluate labour laws. Furthermore, even though there is a lively debate on the scope and the extent of labour law protection, the 'inequality of bargaining power' rationale is - in this writer's view - sufficiently defined and elaborated in order to serve as (a part of) a normative framework for evaluative or normative research.

However, it is problematic to restrict the normative framework to 'countervailing inequality' or 'protecting the worker' when we know that all labour law reforms since the 1980s have been informed by widely differing policy objectives, ${ }^{19}$ not in the least the neoliberal policy to make the labour markets more 'flexible' and competitive (Dukes, 2017, p. 66). Especially the more recent (and often comprehensive) reforms following the economic crisis have been characterized by a 'regressive dismantling' of workers' rights (Giubboni, 2018, p. 8). ${ }^{20}$

The broader approach that has been identified has the advantage of involving a wider range of policy goals. However, there is no consensus on what principles should be included, how they should be interpreted and how they relate to each other. In other words, the broader approach leads to a less clearly defined normative framework. ${ }^{21} \mathrm{~A}$ few scholars have explicitly engaged with the question of the normative underpinnings of labour law with the aim of providing a set of stand-

19 In fact, when we go into the details of statutory employment rights, we find very diverse justifications (Bogg, 2017, p. 20).

20 Giubboni reports that Italian scholars have described the Italian reforms as a 'radical questioning of the traditional protective and emancipatory goals of labour law, to such an extent that we would have witnessed a change of the very "scientific paradigm" of that (once) autonomous legal discipline and normative field'.

21 It is difficult to make general statements about the status of labour law scholarship of every jurisdiction. For Netherlands, however, it can be said that the so-called foundations of labour law and social security law are not yet fully developed in the literature. See e.g. Eleveld (2012, pp. 28-29), Noordam (1997, pp. 107-120) and Zekić (2011, pp. 59-72). 
ards or values that can serve to support a normative judgment, ${ }^{22}$ but these sets of standards seem not to be objective and authoritative enough (Brenninkmeijer \& Heerma van Voss, 2001, pp. 975-982; Dukes, 2017). Furthermore, such principles are rarely absolute. They can lead the normative judgment in many directions, since they are general and vague, sometimes even conflicting with each other. ${ }^{23}$ It is interesting to notice that even though these basic principles as mentioned in this contribution can be considered as internal to labour law, at least some of them imply that an interdisciplinary approach is necessary (cf. Eleveld, 2012, pp. 28-29). While some of the mentioned principles, such as social inclusion and income security seem to be in need of a more empirical approach, others clearly ask for a philosophical approach. The questions 'what are the foundations of labour law' and 'what should labour law be' are, of course, part of the 'bigger' question about the goal or purpose of law. By asking such questions, we enter the field of political philosophy. Luckily, there has recently been a growing interest in philosophical perspectives on labour law (Bogg, 2017, p. 8) ${ }^{24}$ However, a lot of work still needs to be done, since labour law study has until now 'largely been deaf to developments in the field of political philosophy' (Cabrelli \& Zahn, 2017b, p. 10; also see Collins, 1997, p. 297). When dealing with normative questions, most labour lawyers still try to approach the matter primary from an internal perspective. For example, while calling redistribution a 'major goal of labour law', Davidov (2016, p. 59) pays scant attention to the different theories on just distribution and concludes that it is not necessary to explain 'in what sense exactly' the outcomes of private law rules are not fair and what type of equality we should pursue. ${ }^{25}$

\section{Conclusion}

Labour law scholars often engage with the questions of what the law should be and how it should be drafted or applied. Such questions ultimately involve value judgments. The use of empirical methods may help us make value judgments - and as such, empirical research should be encouraged - but empirical facts cannot replace value judgments. In the end, the normative questions remain. One can argue that it is not for legal scholars to decide on these questions, but for the democratically chosen legislature. In that sense, it is certainly true that not the lawyers, but

the forces of political economy will almost certainly determine the individual and collective fate of workers, as they have been doing for the past three or four decades of neoliberal globalization (Arthurs, 2017, p. 13). see, e.g., Bogg (2015, pp. 73-106).

23 It is known that even fundamental rights, which can be regarded as codifications of general, unwritten legal principles, can offer little guidance when concrete conflicting interests are at stake; see, e.g., Gerards (2006).

24 See besides the other references mentioned here, Collins et al. (2018).

25 He does further develop this, however, in his chapter 'Distributive Justice and Labour Law' in Collins et al. (2018, pp. 141-155). 
This does not mean, however, that the normative questions as such should not or cannot be studied by legal scholars as social scientists. As in any other legal field, scholars in labour law need a normative framework when discussing normative questions.

The internal normative framework of labour law is a complex framework comprised of different - sometimes conflicting - principles. This framework is too complex to be summarized as 'protection of the worker'. This is not strange when we consider that labour law is, as articulated by Hepple, 'the outcome of struggles between different social actors and ideologies, of power relationships' (Hepple, 2011, p. 30). That leaves us with the task of further defining that framework. However, ultimately, it may be inevitable that the normative framework - as elaborated as it can be - will never lead us in only one direction. This does not have to be problematic. It is certainly possible to favour a pluralistic scheme and the coexistence of different goals for the discipline (Cabrelli \& Zahn, 2017, p. 10). When we ask the question what the law ought to be, there is not only one true answer (Smits, 2009, p. 93). The values may be abstract, but they help to explain and justify labour laws (Davidov, 2016, p. 62).

However, it is good to be aware that the normative framework that emerges from the labour law literature with its emphasis on inequality, emancipation, human dignity and human freedom may not always reflect the current state of labour law in a given country. The 'true' picture might be (much) grimmer, one where the market principles such as efficiency and competitiveness play a much bigger role. Adams and Deakin have argued that in order to be influential in policymaking, the analysis of labour law needs to engage with the empirical claims made by 'the new orthodoxy', which only sees labour law as an employment intrusion, an undesirable distortion of the market (Adams \& Deakin, 2017, p. 33). According to them, rebuttals of a normative kind are often ignored or misinterpreted by policymakers. However, adopting the labour market approach and focusing only on efficiency carry with it the danger of placing significant limitations on the kind of normative arguments that scholars can make (Dukes, 2017, p. 60). Furthermore, it also rests on a (different) normative framework. That is why principles such as equality, redistribution, emancipation, human dignity and human freedom can play a role in labour law scholarship even when they are not leading principles for policymakers.

We see that there is a plurality of research methods even within one legal field. ${ }^{26}$ That means that legal scholars can be creative in choosing the angle from which they approach their research subject. If they choose to refer to the underlying principles of the legal field in question, they have a large degree of freedom in regard to how to employ them, since we are far from agreement on their concrete meaning. This realization fits well with the nature of legal discipline as an argumentative discipline (cf. Bogg, 2017, p. 34). However, there are great risks attached to this 'pervasive legal instrumentalism' (van Gestel \& Micklitz, 2014, pp. 303307). Therefore, this pluralism and freedom come with the responsibility to be Belgian PhD's in social security law written between 1945 and 2012, Kestemont (2016b). 
open and explicit about the methods employed (Kestemont, 2016b, p. 236) and about the normative framework used. When using the underlying principles as the normative frame of reference, a scholar should elaborate on them, show the different meanings of the principles, be open about where he or she stands and about the assumptions on which that position is based, but also show the counterpositions and counterarguments, as well as the limits of this approach. By doing this, the normative framework itself can be further developed in future research.

\section{References}

Z. Adams \& S. Deakin, 'Quantitative Labour Law', in A. Ludlow \& A. Blackham (Eds.), New Frontiers in Empirical Labour Law Research, Oxford, Hart Publishing, 2017, p. 31-50.

H. Arthurs, 'Labour Law after Labour', in G. Davidov \& B. Langille (Eds.), The Idea of Labour Law, Oxford, OUP, 2011, p. 13-29.

H. Arthurs, 'Can Davidov's Legal Slingshot Slay the Goliath of Political Economy - On Guys Davidov's A Purposive Approach to Labour Law, Jerusalem Review of Legal Studies, Vol. 16, No. 1, 2017, p. 1-14.

D. Ashiagbor, The European Employment Strategy: Labour Market Regulation and New Governance, Oxford, OUP, 2005, pp. 217-241.

D. Ashiagbor, 'Collective Labor Rights and the European Social Model', Law \& Ethics of Human Rights, Vol. 3, No. 2, 2009, pp. 222-266.

J. Bell, 'Legal Research and the Distinctiveness of Comparative Law', in M. Van Hoecke (Ed.), Methodologies of Legal Research. Which Kind of Method for What Kind of Discipline?, Oxford, Hart Publishing, 2011, pp. 155-176.

A. Blackham \& A. Ludlow, 'Introduction', in A. Ludlow \& A. Blackham (Eds.), New Frontiers in Empirical Labour Law Research, Oxford, Hart Publishing, 2017, p. 1.

A. Bogg, 'Labour Law and the Trade Unions: Autonomy and Betrayal', in A. Bogg, C. Costello, A.C.L. Davies \& J. Prassl (Eds.), Autonomy of Labour Law, Oxford, Hart Publishing, 2015, pp. 73-106.

A. Bogg, 'Labour, Love and Futility: Philosophical Perspectives on Labour Law', International Journal of Comparative Labour Law and Industrial Relations, Vol. 33, No. 1, 2017, p. 7-37.

A.F.M. Brenninkmeijer \& G.J.J. Heerma van Voss, 'Beginselen van sociale rechtsvorming. Bespreking preadvies NJV', NJB, Vol. 76, No. 21, 2001, pp. 975-982.

N. Bruun \& B. Hepple, 'Economic Policy and Labour Law', in B. Hepple \& B. Veneziani, The Transformation of Labour Law in Europe, Hart Publishing 2009, 31-57.

N. Bruun, K. Lörcher \& I. Schömann (Eds.), The Economic and Financial Crisis and Collective Labour Law in Europe, London, Hart Publishing, 2014.

D. Cabrelli \& R. Zahn, 'Theories of Domination and Labour Law: An Alternative Conception for Intervention?', International Journal of Comparative Labour Law and Industrial Relations, Vol. 33, No. 3, 2017a, pp. 339-364.

D. Cabrelli \& R. Zahn, 'Civic Republican Political Theory and Labour Law', Edinburgh School of Law Research Paper No. 2017/11, 2017b.

H. Collins, 'The Productive Disintegration of Labour Law', Industrial Law Journal, Vol. 26, 1997, p. 295-309.

H. Collins, G. Lester \& V. Mantouvalou (Eds.), Philosophical Foundations of Labour law, Oxford, OUP, December 2018. 
W. Däuble, 'Labour Law and Competition', in M. Rigaux, J. Buelens \& A. Latinne (Eds.), From Labour Law to Social Competition Law?, Intersentia, 2014, pp. 58-59.

G. Davidov, A Purposive Approach to Labour Law, Oxford, OUP, 2016.

G. Davidov \& P. Alon-Shenker, 'Special Issue: Labour Law Research Methodologies Editors' Introduction', International Journal of Comparative Labour Law and Industrial Relations, Vol. 33, No. 1, 2017, p. 1-5.

G. Davidov \& B. Langille (Eds.), The Idea of Labour Law, Oxford, OUP, 2011.

S. Deakin, 'The Many Futures of the Contract of Employment', in J. Conaghan, R.M. Fischl \& K. Klare (Eds.), Labour Law in an Era of Globalization: Transformative Practices and Possibilities, Oxford, OUP, 2002, p. 177-196.

S. Deakin \& F. Wilkinson, The Law of the Labour Market: Industrialization, Employment and Legal Evolution, Oxford, OUP, 2005.

R. Dukes, The Labour Constitution. The Enduring Idea of Labour Law, Oxford, OUP, 2014.

R. Dukes, 'Identifying the Purposes of Labour Law: Discussion of Guy Davidov, A Purposive Approach to Labour Law', Jerusalem Review of Legal Studies, Vol. 16, No. 1, 2017, p. 52-67.

A. Eleveld, 'Arbeidsplicht, rechtvaardigheid en de grondslagen van het socialezekerheidsrecht', Netherlands Journal of Legal Philosophy, Vol. 41, No. 1, 2012, pp. 28-53.

A. Eleveld, 'Argumentative Strategies in the Defence of Labour Law: The Promise of Republican Theory', in A. Blackham, M. Kullmann \& A. Zbyszewska (Eds.), Theorising Labour Law in a Changing World, Oxford, Hart Publishing, 2019, pp. 207-222.

M. Freedland, 'Otto Kahn-Freund, the Contract of Employment and the Autonomy of Labour Law', in A. Bogg, C. Costello, A.C.L. Davies \& J. Prassl (Eds.), Autonomy of Labour Law, Oxford, Hart Publishing, 2015, pp. 29-44.

M. Freedland \& N. Kountouris, The Legal Construction of Personal Work Relations, Oxford, OUP 2011, pp. 371-376.

J. Fudge, 'Labour as a 'Fictive Commodity", in G. Davidov \& B. Langille (Eds.), The Idea of Labour Law, Oxford, OUP, 2011, p. 120-136.

H. Genn, M. Partington \& S. Wheeler, Law in the Real World - Improving Our Understanding of How Law Works: Final Report and Recommendations, London, Nuffield Foundation, 2006.

J.H. Gerards, Belangenafweging bij rechterlijke toetsing aan fundamentele rechten, oratie Universiteit Leiden, Alphen a/d Rijn, Kluwer, 2006.

S. Giubboni, 'The Rise and Fall of EU Labour Law', European Law Journal, Vol. 24, No. 1, 2018, p. 7-20.

S. Hammond \& P. Ronfeldt, 'Legal Methods: Asking New Questions about Law and the World of Work', in K. Whitfield \& G. Strauss (Eds.), Researching the World of Work: Strategies and Methods in Studying Industrial Relations, Ithaca and London, ILR Press, 1998, p. 227-238.

F. Hendrickx, 'Arbeidsrecht voor de spiegel', Revue de droit social, No.1, 2010a, p. 3-59.

F. Hendrickx, 'The Future of Collective Labour Law in Europe', European Labour Law Journal, Vol. 1, No. 1, 2010b, pp. 59-79.

B. Hepple, 'Factors Influencing the Making and Transformation of Labour Law in Europe', in G. Davidov \& B. Langille (Eds.), The Idea of Labour Law, Oxford, OUP 2011, p. 30-42.

A. Hinarejos, 'Changes to Economic and Monetary Union and Their Effects on Social Policy', International Journal of Comparative Labour Law and Industrial Relations, Vol. 32, No. 2, 2016, pp. 231-250.

J. Howe, A. Chapman \& I. Landau, 'The Evolving Project of Labour Law in Australia', in J. Howe, A. Chapman \& I. Landau (Eds.), The Evolving Project of Labour Law: Foundations, Development \& Future Research Directions, Sydney, The Federation Press, 2017a, p. 1-21. 
J. Howe, A. Chapman \& I. Landau (Eds.), The Evolving Project of Labour Law: Foundations, Development \& Future Research Directions, Sydney, The Federation Press, 2017b.

L. Kestemont, 'A Meta-methodological Study of Dutch and Belgian PhD's in Social Security Law: Devising a Typology of Research Objectives as a Supporting Tool', European Journal of Social Security, Vol. 17, No. 3, 2015, p. 361-384.

L. Kestemont, Towards a Legal Methodology. An Explicit Methodological Framework for Academic Legal Research in Social Security Law (dissertation KU Leuven), 2016a.

L. Kestemont, Naar een rechtswetenschappelijke methodenleer. Een expliciet methodologisch kader voor rechtswetenschappelijk onderzoek in het socialezekerheidsrecht, KU Leuven, 2016b.

B. Langille, 'What Is International Labor Law For?', Law \& Ethics of Human Rights, 2009, Vol. 3 No.1, pp. 73-76.

J. Malmberg \& T. Sigeman, 'Industrial Actions and EU Economic Freedoms: The Autonomous Collective Bargaining Model Curtailed by the European Court of Justice', Common Market Law Review, Vol. 45, No. 4, 2008, p. 1115-1146.

F.M. Noordam, 'Een kontje van de wetgever', in: L. Betten et al. (Eds.), Ongelijkheidscompensatie als rode draad in het recht, Deventer, Kluwer, 1997, pp. 107-120.

A. O'Donnell, 'When Was 'Labour Law', in J. Howe, A. Chapman \& I. Landau (Eds.), The Evolving Project of Labour Law: Foundations, Development \& Future Research Directions, Sydney, The Federation Press, 2017, p. 60-71.

J. Rawls, A Theory of Justice, Cambridge, Belknap, 1971.

O. Razzolini, "The Need to Go Beyond the Contract: "Economic" and "bureaucratic" Dependence in Personal Work Relations', Comparative Labor Law \& Policy Journal, Vol. 31, 2010, p. 267-301.

M. Rood, 'Internationalization: A New Incentive for Labour Law and Social Security Law', in B. Aaron, J.R. Bellace \& M. Rood, Labour Law at the Crossroads: Changing Employment Relationships. Studies in Honour of Benjamin Aaron, Den Haag, Kluwer Law International, 1997, p. 139-154.

S. Slinn, 'The Limitations of Pieces of Paper: A Role for Social Science in Labour Law', Canadian Labour and Employment Law Journal, Vol. 12, 2005, p. 291-311.

J.M. Smits, 'Redefining Normative Legal Science: Towards an Argumentative Discipline', in F. Coomans, M. Kamminga \& F. Grunfeld (Eds.), Methods of Human Rights Research, Intersentia, Antwerp-Oxford, 2009a, pp. 45-58.

J.M. Smits, Omstreden rechtswetenschap. Over aard, methode en organisatie van de juridische discipline, Den Haag, Boom Juridische uitgevers, 2009b.

H. Spector, 'Philosophical Foundations of Labor Law', Florida State University Law Review, Vol. 33, 2006, p. 1119-1143.

H.S. Taekema, 'Theoretical and Normative Frameworks for Legal Research: Putting Theory into Practice', Law and Method, 2018, p. 1-17.

A. Todoli-Signes, 'The End of the Subordinate Worker? The On-Demand Economy, the Gig Economy, and the Need for Protection for Crowdworkers', International Journal of Comparative Labour Law and Industrial Relations, Vol. 33, No. 2, 2017, pp. 241-268.

U.M. Unger, The Critical Legal Studies Movement: Another Time, a Greater Task, Cambridge, Cambridge University Press, 1986.

P.F. van der Heijden \& F.M. Noordam, De waarde(n) van het sociaal recht. Over beginselen van sociale rechtsvorming en hun werking, preadvies NJV, Deventer, W.E.J. Tjeenk Willink, 2001.

R. van Gestel \& H.W. Micklitz, 'Why Methods Matter in European Legal Scholarship', European Law Journal, Vol. 20, No. 3, May 2014, pp. 292-316.

T. van Peijpe, Employment Protection under Strain (Sweden, Denmark, The Netherlands), The Hague, Kluwer Law International, 1998. 
M. Weiss, 'Re-Inventing Labour Law?' in G. Davidov \& B. Langille (Eds.), The Idea of Labour Law, Oxford, OUP 2011, pp. 43-56.

P.C. Westerman, 'Open or Autonomous? The Debate on Legal Methodology as a Reflection of the Debate on Law', in M. Van Hoecke (Ed.), Methodologies of Legal Research. Which Kind of Method for What Kind of Discipline?, Oxford, Hart Publishing, 2011, p. 87-110.

World Bank, The World Development Report 2019: The Changing Nature of Work, Working Draft, June 8, 2018.

N. Zekić, 'Arbeidsrechtelijk normatief kader en ongelijkheidscompensatie', in W. Plessen, H. van Drongelen \& F. Hendrickx (Eds.), Sociaal Recht: tussen behoud en vernieuwing, Zutphen, Uitgeverij Paris, 2011, pp. 59-72.

N. Zekić, 'Job Security or Employment Security: What's in a Name?', European Labour Law Journal, Vol. 7, No. 4, 2016, pp. 548-575. 